\title{
The Immigration Act of 1990: Retreat from Reform
}

\section{Vernon M. Briggs, Jr.}

Cornell University

It is difficult to understand why anyone would editorially "rejoice", as has been done, over the immigration legislation passed by Congress on the last day of the 101st Congressional session (N.Y. Times, 1990, p. A. 14). The new statute, which was signed into law by President George Bush on November 29, 1990, is ill conceived, deceptively designed, poorly timed, and subtly racist. Despite the chronic need for reform, the Immigration Act of 1990 cannot possibly be described as being in the national interest. It perpetuates and expands the worst features of the existing system while introducing new features that are both counterproductive and, in parts, unethical in the principles it projects.

Although the law is multifaceted, its supporters used the myth of pending labor shortages as the primary justification for their actions. There is absolutely no evidence to support this premise. Over the decade of the 1980 s the U.S. labor force grew at a rate and in numbers unparalleled by any other industrialized nation. While the projected annual rate of increase for the $1990 \mathrm{~s}(1.2 \%)$ is below the realized rate of the early $1980 \mathrm{~s}(2 \%)$, it is still expected to be substantial in absolute numbers. Before this legislation was enacted, the Department of Labor's conservative projections predicted an average net growth of 1.6 million workers a year through to the year 2000 (Fullerton, 1989). In absolute terms, the labor force is projected to increase by $16 \%$ in this decade (or by 19.5 million additional workers). Hence, there was no general need for more worker immigrants per se. With this legislation, legal immigration will increase by at least $35 \%$ over its already high level plus whatever number of refugees and illegal immigrants come in addition. 
While there is no prospect for a general labor shortage in the 1990s, there is a likelihood of serious spot shortages of qualified labor. These shortages will be most apparent in the range of occupations that require extensive training and educational preparation. There is no shortage now nor any prospect of a future labor shortage for jobs that require little in the way of human capital for job applicants. In the technologically-driven and internationally competitive economic setting of the 1990s, no industrialized nation that has 27 million functionally illiterate adults and another 20 million marginally literate adults need have any fear of shortage of unqualified workers (Kozel, 1985, pp. 3-12).

In this evolving environment, a targeted immigration policy designed to admit a limited number of highly skilled and educated workers is what is required. The new immigration law ostensibly was designed to move in this direction but, in actuality, it expands the nepotistic family reunification focus that is the predominate feature of the existing law. It is the inordinate adherence to this principle of family reunification-with its total absence of concern for human resource considerations-as well as the continuing entry of illegal immigrants and admission of third world refugees that are the major causes of this worsening mismatch between the qualifications of may job seekers and the actual needs of the labor market.

Moreover, immigration in one of the key explanations for the mounting adult illiteracy problem in the United States. A 1990 study of the economic impact of recent immigrants found that "more recent immigrant waves have relatively less schooling, lower earnings, lower labor force participation, and higher poverty rates than earlier waves at similar stages of their assimilation into the country" (Borjas, 1990, p. 20). What the reform legislation should have done was to dramatically reduce the family reunification entry route. Instead, it significantly increases the numbers of immigrants who can enter without direct regard as to their labor market qualifications.

The new legislation does place an overall cap on family-related immigration for the first time since the nation acted to place any numerical restrictions on immigration in the 1920s. But the cap will still result in a considerable increase in family-related immigration over existing levels. It is also true that the Immigration Act of 1990 increases the absolute number of persons who can be annually admitted to meet labor market needs (from the present 54,000 work-related visas to 140,000 work-related visas' a year) but this concern still remains the secondary focus of immigration policy. Indeed, with the new increase in the total number of immigrants permitted under the law to 700,000 persons a year, the actual percentage of the allowable visas granted to meet demonstrated labor market needs 
under the new legislation is exactly the same as under the prevailing system (i.e., 20\%). No change in emphasis can hardly be seen as a step forward for public policy.

All so-called "work-related immigrants" will be admitted each year into the indefinite future regardless of the state of the economy at any given time. It would have been preferable for economic policymaking if the number of work-related immigrants in the legislation was defined as a ceiling but not as an annual goal. The actual number to be admitted in any year should be a flexible figure that is set administratively by a branch of government (e.g., the U.S. Department of Labor) concerned with employment levels, human resource development, and equal employment opportunity. The decision of this agency should then be annually defended before an appropriate congressional committee (e.g., the Joint Economic Committee).

Even use of immigration as a source of experienced workers should be viewed as a policy of last resort, not immediate recourse. It should be used in consort with other public policy measures intended to develop the employment potential of the nation's human resources. Labor shortages, should they develop, should not be viewed as a problem to be solved immediately by immigration. Rather, labor shortages should be viewed as an opportunity to educate youth; to retrain adults; to eliminate discriminatory barriers; and to introduce voluntary relocation programs to assist would-be workers to move from labor surplus to labor shortage areas. The national priority must always be to prepare citizen workers for jobs in the expanding employment sectors of the economy. To respond immediately to labor shortages by using immigration policy to fill jobs in an economy that is not at full employment is analogous to proposing to take a shortcut through quicksand. Immigrants can fill the jobs, but the social cost to the nation is a loss of opportunities for citizens with all of the attendant social and human costs.

In a dynamic industrialized economy such as that of the United States, shortages for qualified workers in some occupations can be expected to occur from time to time. These shortages cannot always be overcome by simply raising wages. In most instances, the shortages can be expected to occur in occupations that require extensive educational and training preparation. In the long run, the nation's human resource strategy should also be to prepare citizens for these jobs. Hence, the actual number of work-related visas granted each year should be flexible, and that number should include the option of being anywhere from zero to the politically set ceiling (e.g., 140,000 under the new law). As presently designed, the new law - with its fixed annual infusion of work-related immigrants-can be 
expected to dampen the market pressures desperately needed to improve the nation's human resource development system.

In addition to its general misdirection, the Immigration Act of 1990 includes a host of dubious categories of workers to be admitted at part of the 140,000 work-related immigrants. For instance, it reserves 10,000 visas a year for the admission of millionaire "investors" who "promise" to create at least 10 jobs. This should be viewed as a source of shame. It introduces the principle that the rich of the world can buy their way into the United States. Never before has such a concept been embraced by immigration law. Aside from the fact that it will be almost impossible to enforce, it represents a reward of privilege that is unworthy of legal protection. The major beneficiaries of this new entry standard are the nation's immigration lawyers who were its chief proponents. Rewarding personal greed should have no place in the nation's immigration system. Another questionable category is the inclusion within the 140,000 visas a category of "special immigrants" that gives priority to religious workers-a nebulous category that begs for opportunistic abuse.

The new legislation could not be more poorly timed. When it passed, the U.S. economy was entering into a period of recession. No one knows how long this downturn may last but one can be certain that there will be other periodic cyclical fluctuations in the future. In such times of such adversity, the last thing that citizen workers need is more competition from an expanded number of immigrant job seekers regardless of whether they are admitted on the basis of family or work-related criteria. But under this new law, they will all come every year regardless of their effect on opportunities for citizens. Under present circumstances, the most endangered of these citizen workers are those who are from minority groups who seek work in large urban centers (e.g., New York City, Los Angeles, or Miami). In the area of equal employment opportunity, too much attention has been paid to the speculative benefits that might have been lost by the veto by President Bush of the Civil Rights Act of 1990 and too little given to the civil rights costs that can be anticipated from the Immigration Act of 1990 crafted by Congress.

The new legislation raises other serious issues about its racial intentions. It creates another new admission class that reserves 40,000 visas for immigrants from countries that have supposedly been adversely affected by the nondiscriminatory admission system of the existing law. Most of those eligible for this restricted category will be from Europe-in fact, $40 \%$ of the visas (or 16,000) for the first three years are specifically reserved for persons from one European country-Ireland. Such action turns the national debate over ethnic diversity on its head. The most admirable charac- 
teristic of the present immigration system that was established in 1965 is that it eliminated national origin as an influencing factor in the immigrant admission process. This new law resurrects this sinister issue. The fact that most of these diversity immigrants will be from nations that can be expected to supply nonHispanic whites can only be seen as a retreat from the commitment to national origin neutrality that has been the hallmark of immigration policy for the past 25 years.

There are a host of other provisions in this legislation whose potential economic effects are anyone's guess. The introduction of the concept of "safe haven," for instance, that specifically allows persons who do not qualify as refugees but whose countries are engaged in civil unrest to stay and to work in the United States for up to 18 months is an open invitation to abuse. Persons from El Salvador are specifically protected (this provision alone could cover as many as 400,000 persons) but it could apply to a multitude of situations. There is another provision that will allow perhaps 50,000 World War II veterans from the Philippines to naturalize their status to become U.S. citizens. The list of other beneficiaries from this omnibus piece of legislation could go on and on.

Once more, political considerations have dominated the design of the nation's immigration policy. Although every aspect of these admissions decisions is fraught with economic effects, the labor market implications have not been thought out.

Except for the modifications designed to correct some of the out-dated political and life style criteria that have arbitrarily been used to exclude some potential immigrants from qualifying for entry, the Immigration Act of 1990 deserves no praise. It does not address the nation's human resource needs. To the contrary, it aggravates existing problems and adds a host of new sources of contention. One can only hope that Congress has second thoughts about what it has done and considers modifications before this legislation takes effect on October 1, 1991.

\section{REFERENCES}

Borjas G. (1990). Friends or strangers: The impact of immigrants on the U.S. Economy. New York: Basic Books.

Fullerton, H.N. (1989). New labor force projections, spanning 1988 to 2000. Monthly Labor Review, (November), pp. 3-12.

Kozel, J. (1985). Illiterate America. Garden City, N.Y: Anchor/Doubleday.

New York Times. (October 29, 1990). Two reasons to rejoice on immigration. 